recovery sleep. The main SWS delta activity increase was for stage 3 during the first half of the night following afternoon exercise, and this seems to be partially counterbalanced by a non-significant decrease during the second half of the night, resulting in no significant overall changes. If SWS reflects enhanced protein synthesis and body restitution ${ }^{1}$, then in view of the high workload imposed, more substantial changes in SWS might have been expected. It must be concluded that if a heavy, but tolerable, workload is imposed early in the day then ensuing wakefulness is sufficient for recovery. If this exercise is given later in the day, however, then ensuing wakefulness may not be adequate for recovery, and some of the recovery process may intrude into the earlier part of sleep and be reflected in the sleep EEG.

Department of Human Sciences,

J. A. HORNE

J. M. PORTER

Loughborough University,

Loughborough,

Leicestershire, UK

Received May 16; accepted June 2, 1975.

1 Oswald, 1., Nature, 223, 893 (1969)

2 Sassin, J. F., et al., Science, 165, 1299 (1969).

3 Baekeland, F., and Lasky, R., Percept. Mot. Skills, 23, 1203 (1966).

Zloty, R. B., Burdick, J. A., and Adamson, J. D., Activ. nerv. sup. (Praha), 15, 217 (1973).

${ }^{5}$ Hauri, P., Psychophysiology, 4, 267 (1968)

6 Zir, L. M., Smith, R. A., and Parker, D. C., J. clin. Endocr., 32, 662 (1971).

Adamson, L., Hunter, W. M., Ogunremi, O. O., Oswald, I., and Percy-Robb, I. W., J. Endocr., 62, 473 (1974)

${ }^{8}$ Rechtschaffen, A., and Kales, A., A Manual of Standardised Terminology, Techniques and Scoring System for Sleep Stages of Human Subjects (US natn. Inst. Hith, No. 204, 1968)

9 Astrand, 1., Acta physiol. scand., 49, suppl., 169 (1960).

\section{Dihydroactinidiolide in the supracaudal scent gland secretion of the red fox}

IN spite of growing interest in the function of skin glands in mammalian chemical communication ${ }^{1,2}$, little is known of either the chemical nature or the behavioural significance of the secretion of the supracaudal (tail) scent gland of the red fox (Vulpes vulpes). A recent paper ${ }^{3}$ reports observations concerning the histology and histochemistry of this gland, including findings of unusual fluorescent sebum constituents. In this paper, preliminary gas chromatographic-mass spectrometric data are presented indicating the presence of dihydroactinidiolide (I) and related compounds in this secretion and the significance of this finding is discussed.

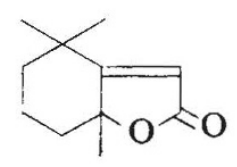

I

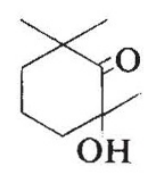

II

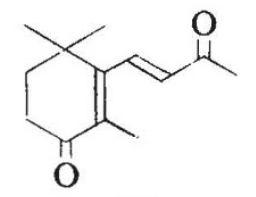

III
Particles of waxy yellow-brown stale secretion were separated manually from the hair and skin surface of the supracaudal gland region of eleven male red fox (taken wild, February 14, 1974-April 19, 1974, Wales), bulked (67 mg) and distilled (at $170^{\circ} \mathrm{C}$, air bath temperature, $0.02 \mathrm{mmHg}$ ). The distillate was examined by combined gas chromatography-mass spectrometry (AEI MS30 mass spectrometer $(24 \mathrm{eV})$ with a Pye-Unicam 104 gas chromatograph fitted with a $2 \mathrm{~m} \times 2 \mathrm{~mm}$ internal diameter glass column of $2 \%$ SE-33 on $80-100$ mesh Gas Chrom Q; column temperature $116^{\circ} \mathrm{C}$ to $280{ }^{\circ} \mathrm{C}$ at $5{ }^{\circ} \mathrm{C}$ min $^{-1}$; injector temperature $170^{\circ} \mathrm{C}$; separator temperature $200 \mathrm{C}$ ) following treatment with diazomethane.

A number of volatile components exhibiting mass spectra suggesting monoterpenes or related compounds were observed in advance of the range of saturated carboxylic acids (starting at $\mathrm{C}-14$, observed as methyl esters) and related compounds expected in a distillate of skin lipids. These more volatile compounds included substances possessing the following observed mass spectra (five most intense ions, plus other significant ions) indicating dihydroactinidiolide $(\mathrm{I})^{4} \mathrm{~m} / \mathrm{e} 180$ $\left(\mathrm{M}^{+}, 22\right), 165(7), 152(11), 137(30), 111(100), 109(30), 43(25)$; 6-hydroxy-2,2,6-trimethylcyclohexanone (II) $)^{5} \mathrm{~m} / \mathrm{e} 156\left(\mathrm{M}^{+}, 6\right)$, 128 (31), $110(35), 95(39), 71(100), 58(34), 43(36)$; and trans-4-keto- $\beta$-ionone (III) ${ }^{6} \mathrm{~m} / \mathrm{e} 206\left(\mathrm{M}^{+}, 47\right), 191$ (15), 177 (6), 164 (38), 163 (91), 121 (53), 43 (100), 41 (38). Other major volatile terpenoid constituents of the secretion distillate are under investigation.

The identity of dihydroactinidiolide was confirmed by gas chromatographic coinjection with authentic material, m.p. $42-43{ }^{\circ} \mathrm{C}$ (retention time $4.1 \mathrm{~min}, 1.5 \mathrm{~m} \times 2 \mathrm{~mm}$ internal diameter glass column of $5 \%$ Dexsil $300-$ GC on $80-100$ mesh Chromosorb W, AW; column temperature $172{ }^{\circ} \mathrm{C}$, isothermal). A peak of the same retention time was also noted when a thin-layer chromatography fraction (acetone pre-eluted silica gel G (Merck type 60), $R_{\mathrm{f}} 0.06$ to 0.2 with diethyl ether-petroleum spirit $\left.\left(60-80^{\circ} \mathrm{C}\right), 30 / 70, \mathrm{v} / \mathrm{v}\right)$ of a methanol-chloroform extract of stale secretion was examined by gas chromatography (dihydroactinidiolide, $R_{f} 0.08$ ). The level of dihydroactinidiolide in this sample of stale secretion was $<50$ p.p.m.

This is the first report of volatile terpenes in an external mammalian glandular secretion, although it was expected that such compounds might be involved in mammalian communication following the elucidation of the olfactory response of certain Felidae to cis-trans-nepetalactone, a major constituent of the essential oil of the catnip plant, Nepeta cataria? The early description of the supracaudal gland as the 'violet gland' on account of its odour also suggested such a finding. A number of terpenoid constituents of the plant Actinidia polygama, including dihydroactinidiolide, are also reported to have behavioural effects on certain Felidae ${ }^{8}$.

The presence of photolabile fluorescent compounds has been reported in the red fox supracaudal gland sebum, and fluorescence and ultraviolet spectra have been described ${ }^{3}$. Field desorption mass spectrometry of the major non-polar fluorescent fraction (Varian $\mathrm{CH} 5 \mathrm{D}$, source temperature $80^{\circ} \mathrm{C}$, emitter current $8 \mathrm{~mA}$ ) revealed major ions at $m / e 524,525$, 550 and 552 (no ions in range $m / e$ 554-1,200) indicating the presence of compounds in the carotenoid mass range. If carotenoids are present, their occurrence could be related to the presence of volatile terpenes in the secretion ${ }^{9}$.

I thank Professor A. H. Jackson, Dr D. E. Games, Professor M. C. Whiting and Dr J. Macmillan for access to mass spectrometric and other facilities, Dr S. R. Heller for conducting a mass spectral data file search, Mr H. G. Lloyd and staff for providing biological material, Dr S. Isoe for providing an authentic sample of dihydroactinidiolide, Messrs D. Patel, M. Smith, P. Gaskin and K. Taylor for technical assistance and the Nuffield Foundation for financial support.

\section{E. S. Albone}

University of Bristol,

Department of Animal Husbandry,

Langford House, Bristol BSI8 7DU, UK

Received April 3; accepted July 3, 1975.

1 Mykytowycz, R., Advances in Chemoreception, 1, chapter 11 (edit. by Johnston, J. W., Moulton, D. G., and Turk, A.) (Appleton-Century-Crofts, New York, 1970)

2 Birch, M. C. (ed.), Pheromones (North Holland, Amsterdam and London, 1974). 3 Albone, E. S., and Flood, P. F. (in the press)

4 Chen, P. H. Kuhn, W. F., Will, F., and Ikeda, R. M., Org. Mass Spectr., 3, 199-209 (1970).

5 Müggler-Chavan, F., Viani, R., Bricout, J., Marion, J. P., Mechtler, H., Reymond, D., and Egli, R. H., Helv. Chim. Acta, 52, 549-550 (1969).

6 Ina, K., and Eto, H., Agr. Biol. Chem., 36, 1091-1094 (1972).

7 Todd, N. B., J. Hered., 53, 54-56 (1962) and refs therein.

$\checkmark$ Sakan, T., Isoe, S., and Hyeon, S. B., Tetrahedron Lett., 1623-1627 (1967).

9 Isoe, S., Hyeon, S. B., and Sakan, T., Tetrahedron Lett., 279-281 (1969). 